\title{
Stem-like Cells from Invasive Breast Carcinoma Cell Line MDA-MB-231 Express a Distinct Set of Eph Receptors and Ephrin Ligands
}

\author{
MARIANA LUCERO, JASPREET THIND, JACQUELINE SANDOVAL, \\ SHAYAN SENAATI, BELINDA JIMENEZ and RAJ P. KANDPAL
}

Department of Basic Medical Sciences, Western University of Health Sciences, Pomona, CA, U.S.A.

\begin{abstract}
Background/Aim: Breast cancer cell lines consist of bulk tumor cells and a small proportion of stem-like cells. While the bulk cells are known to express a distinct combination of Eph receptors and ephrin ligands, the transcript profiles of stem-like cells in these cell lines have not been adequately characterized. The aim of this study was to determine Eph receptorlephrin ligand profiles of cancer stem cells specific to a triple negative breast carcinoma cell line. Materials and Methods: The normal breast cell line MCF 1OA and the invasive breast carcinoma cell line MDA$M B-231$ were used to isolate $C D 24^{+} / C D 24^{-}$cell populations. The profiles of Eph receptors and ephrin ligands were determined by real-time PCR and the relative abundance in bulk and stem cells were compared. Results: Based on the mean $\triangle C T$ values, the descending order of abundance was as follows. Ephrin-A5 > EPHA2 > (EPHA8, EPHB2) > ephrin-B2 > (EPHA7, EPHB4, ephrin-A4) > ephrin-A3> ephrin-Al $>($ EPHB3, ephrin-B1 $)>$ EPHA4 $>$ EPHAl > EPHA10. EPHA6 and ephrin-A2 transcripts were not detectable in stem cells from either cell line. The expression of EPHA4, EPHA7, EPHA8, and ephrin-A5 in MDA-MB-231 stem cells was up-regulated by 12, 20, 500, and 6.5-fold respectively. Conclusion: The up-regulation of transcripts for EPHA8 and its cognate ligand, ephrin-A5, in the stem cells isolated from $M D A-M B-231$, suggest their involvement in the invasiveness of this cell line. Based on literature reports, we
\end{abstract}

This article is freely accessible online.

Correspondence to: Raj P. Kandpal, Department of Basic Medical Sciences, Western University of Health Sciences, Pomona, CA, 91766, U.S.A. Tel: +1 9097063520, e-mail: rkandpal@westernu.edu

Key Words: Breast carcinoma, stem cells, stem-like cells, triplenegative breast cancer cells, Eph receptors, ephrin ligands, CD44+/CD24- cells, MDA-MB-231 cells. propose the role of EPHA8 and ephrin-A5 in MDA-MB-231 stem cells via the PI3K-AKT-mTOR pathway.

Breast cancer is the leading cause of cancer-related mortality among women globally. According to breast cancer statistics, the majority of breast cancer-related deaths are attributed to the development of secondary tumors that arise via metastasis (1). Triple-negative breast cancer (TNBC) is the most aggressive subtype and accounts for approximately 10-15\% of all cases (1). Accumulating evidence suggests that a small subset of tumor-initiating cells, collectively referred to as breast cancer stem-like cells (BCSCs), are potential drivers of the metastatic progression of breast cancers $(2,3)$. BCSCs are a distinct subset of tumor cells that display the capacity for self-renewal, differentiation, recapitulation of tumor cellular heterogeneity, and tumor cell metastasis (4-6).

Erythropoietin-producing hepatocellular carcinoma (EPH) receptors and their cognate ephrin ligands constitute the largest family of receptor tyrosine kinases (RTKs). Our laboratory has previously demonstrated that the aberrant expression of EPH receptors and ephrin ligands contributes to the invasive characteristics of breast carcinoma cells (79). In the human proteome, there are nine Eph-A receptors (EPHA1-EPHA8 and EPHA10) that bind with high affinity to five GPI-linked ephrin-A ligands (ephrin A1- ephrin A5) (10). Similarly, there are five Eph-B receptors (EPHB1EPHB4, and EPHB6) that bind with high affinity to three ephrin-B ligands that are structurally defined by a single transmembrane-domain and a cytoplasmic PDZ binding domain (11). Eph receptors have prototypical RTK modular architecture as displayed by the highly conserved extracellular and cytoplasmic domains (12). Eph-ephrin interactions can activate intracellular signaling cascades via forward, reverse, and lateral cis mechanisms, which modulate cell adhesion and repulsion dynamics (13). Interestingly, the distinctive spatiotemporal expression patterns of EPH/ephrin membrane proteins in epithelial cells 
can either promote or suppress tumorigenicity (14). In the context of breast cancer, EPHA2 is expressed at low levels in non-tumorigenic human breast epithelial tissue; however, in $60-80 \%$ of human breast carcinomas EPHA2 is overexpressed while its preferred ligand, ephrin-A1, is downregulated (15) substantiating EPHA2 ligand-independent signaling as a mechanism for breast cell tumorigenesis. More recent data suggest the disruption of the Eph/ephrin signaling may also contribute to the acquisition of the breast stem-like phenotype (16). Studies have shown that BCSC self-renewal and differentiation are orchestrated by cells that inhabit the stem cell niche, which employ Eph-ephrins to facilitate cellcell and cell microenvironment communication thereby implicating the Eph-ephrin system as potential regulators of both stem cell and cancer stem cell dynamics.

Therefore, in order to investigate the potential role of EPH-ephrins in the breast cancer stem cell niche, mRNA expression profiles were established for all detectable EPHephrins transcripts in the CD $44^{+} / \mathrm{CD} 24^{-}$and CD $44^{+} / \mathrm{CD} 24^{+}$ cells from two phenotypically distinct breast epithelial cell lines: non-tumorigenic breast epithelial cells (MCF10A) and invasive, triple-negative breast carcinoma cells (MDA-MB231). The comparative analysis of EPH/ephrin transcripts in MCF-10A and MDA-MB-231 from bulk (CD44 ${ }^{+} / \mathrm{CD}_{2} 4^{+}$) and tumor-initiating $\left(\mathrm{CD} 44^{+} / \mathrm{CD} 24^{-}\right)$cell populations indicated distinct expression profiles and suggested an important role for EPHA8 and ephrin-A5 receptor/ligand pair in modulating the invasive phenotype of MDA-MB-231.

\section{Materials and Methods}

Cell culture method. MCF10A (nontumorigenic breast epithelial cells) and MDA-MB-231 (triple-negative, invasive breast carcinoma) cell lines were obtained from American Type Culture Collection (Manassas, VA, USA). MCF-10A cells were maintained in 1:1 DMEM:F12 medium (Thermo Fisher Scientific, Grand Island, NY, USA) supplemented with 5\% horse serum and $0.1 \mu \mathrm{g} / \mathrm{ml}$ Cholera Toxin, and $500 \mathrm{ng} / \mathrm{ml}$ hydrocortisone (Sigma-Aldrich, St. Louis, MO, USA), $10 \mathrm{ng} / \mathrm{ml} \mathrm{EGF} \mathrm{and} 10 \mu \mathrm{g} / \mathrm{ml}$ of insulin (Thermo Fisher Scientific). MDA-MB-231 cells were maintained in DMEM medium (Thermo Fisher Scientific) supplemented with 10\% horse serum from Sigma-Aldrich. The culture medium was supplemented with $5,000 \mathrm{U} / \mathrm{ml}$ of penicillin/streptomycin (Sigma-Aldrich), and the cells were grown in a humidified chamber with $5 \% \mathrm{CO}_{2}$ at $37^{\circ} \mathrm{C}$.

Cancer stem cell separation. The cells $\left(\sim 2 \times 10^{7}\right)$ were rinsed in PBS and suspended in cold $1 \mathrm{X}$ MagCellect Plus Buffer from the MagCellect CD44high CD24low Breast Cancer Stem Cell Isolation Kit (R\&D Systems, Minneapolis, MN, USA). Cells were placed in a polystyrene round bottom tube and $25 \mu$ l of human CD24 biotinylated antibody was added to the cell suspension and incubated for $15 \mathrm{~min}$ at $4^{\circ} \mathrm{C}$. The cell pellet was separated by centrifugation and mixed with sterptavidin for $15 \mathrm{~min}$ at $4^{\circ} \mathrm{C}$. The reaction was placed in a MagCellect magnet (R\&D systems) for 6 min at room temperature after which the supernatant containing the desired $\mathrm{CD} 24^{-/ \mathrm{CD}} 44^{+}$breast cancer stem cells were placed in new tubes. This step was repeated three times. The cells were centrifuged at $300 \times g$ for $8 \mathrm{~min}$, the supernatant was removed, and cells were re-suspended in $0.5 \mathrm{ml}$ of provided buffer and $10 \mu \mathrm{l}$ human CD44 biotinylated antibody and incubated for $15 \mathrm{~min}$ at $4{ }^{\circ} \mathrm{C}$, and cells were centrifuged at $300 \times g$ for $8 \mathrm{~min}$. The cell pellet was resuspended in a buffer with Strepavidin Ferrofluid, mixed gently, incubated for 15 min at $4^{\circ} \mathrm{C}$, and the desired $\mathrm{CD} 44^{\text {high }} \mathrm{CD} 24^{\text {low }}$ cell population separated with a MagCellect magnet.

Total RNA isolation. Total RNA was extracted from the $\mathrm{CD} 44^{+} / \mathrm{CD} 24^{+}$and $\mathrm{CD} 44^{+} / \mathrm{CD} 24^{-}$cell populations isolated from MCF-10A and MDA-MB-231 using the E.Z.N.A. ${ }^{\circledR}$ HP Total RNA Kit (Omega Bio-tek ${ }^{\circledR}$, Norcross, GA, USA). Cell lysate was passed through a 21-gauge syringe 15-20 times and then transferred to a RNA Homogenizer Mini Column. The column was centrifuged, and the eluate was mixed with $70 \%$ ethanol and transferred to a HiBind ${ }^{\circledR}$ RNA Mini Column. The RNA was eluted per the protocol from the vendor. The quality and quantity of isolated RNA was measured using Nanodrop Lite spectrophotometer (Thermo Scientific).

Two-step quantitative PCR. Total RNA $(2 \mu \mathrm{g})$ was converted to cDNA (40 $\mu$ l) using iScript cDNA Synthesis Kit (Omega Bio-tek, Hercules, CA, USA) according to the manufacturer's protocol. The reaction was carried out in a Perkin-Elmer 9600 Gene Amp PCR System by priming for $5 \mathrm{~min}$ at $25^{\circ} \mathrm{C}$, reverse transcription for $20 \mathrm{~min}$ at $46^{\circ} \mathrm{C}$, and incubation for $1 \mathrm{~min}$ at $95^{\circ} \mathrm{C}$. The cDNA was diluted to a concentration of $5 \mathrm{ng} / \mu \mathrm{l}$, and stored in aliquots at $-20^{\circ} \mathrm{C}$. Quantitative PCR (qPCR) was performed by using the StepOnePlus Real-Time PCR System and PowerUp ${ }^{\mathrm{TM}}$ SYBR $^{\mathrm{TM}}$ Green (Applied Biosystems, Foster City, CA, USA). Primers were used to amplify regions that span exon-exon junctions to ensure gene specific amplification. The amplicon sizes for various transcripts ranged from 100 and $500 \mathrm{bp}$. The following cycling protocol was used: UDG activation at $50^{\circ} \mathrm{C}$ for $2 \mathrm{~min}$; DNA polymerase activation at $95^{\circ} \mathrm{C}$ for $2 \mathrm{~min}$; denaturation at $95^{\circ} \mathrm{C}$ for $15 \mathrm{~s}$, annealing at $60^{\circ} \mathrm{C}$ for $15 \mathrm{~s}$, and extension at $72^{\circ} \mathrm{C}$ for $1 \mathrm{~s}$ for 40 cycles. The relative gene expression was calculated using the $\Delta \Delta \mathrm{C}_{\mathrm{T}}$ model (17).

Statistical analysis. Data are expressed as mean \pm S.E.M., and were analyzed using GraphPad Prism version 8.0 (La Jolla, CA, USA). A one-way analysis of variance (ANOVA) was followed by Tukey Kramer or Sidak's post-hoc comparison test. The specific post-hoc tests are outlined in figure legends. For all statistical analysis, means were indicated to be statistically different when $p<0.05$.

\section{Results}

EPH/ephrin transcript expression profiles in $C D 44^{+} / C D 24^{-}$ cells from non-tumorigenic breast epithelial cells (MCF10A). $\mathrm{CD} 44^{+} / \mathrm{CD} 24^{-}$stem-like cells isolated from non-tumorigenic breast epithelial cells (MCF10A) have a unique expression pattern of EPH receptors and ephrin ligands with certain transcripts undetectable under the experimental parameters. Of the $12 \mathrm{EPH}$ receptors and 8 ephrin ligand transcripts profiled, transcripts for EPHA3, EPHA6, EPHA10, and ephrin-A2 were not detectable in MCF10A cells. As shown in Figure 1A, EPHA2 had the highest transcript abundance in $\mathrm{CD} 44^{+} / \mathrm{CD} 24^{-}$cells with a mean $\Delta \mathrm{C}_{\mathrm{T}}$ value of 3.7 


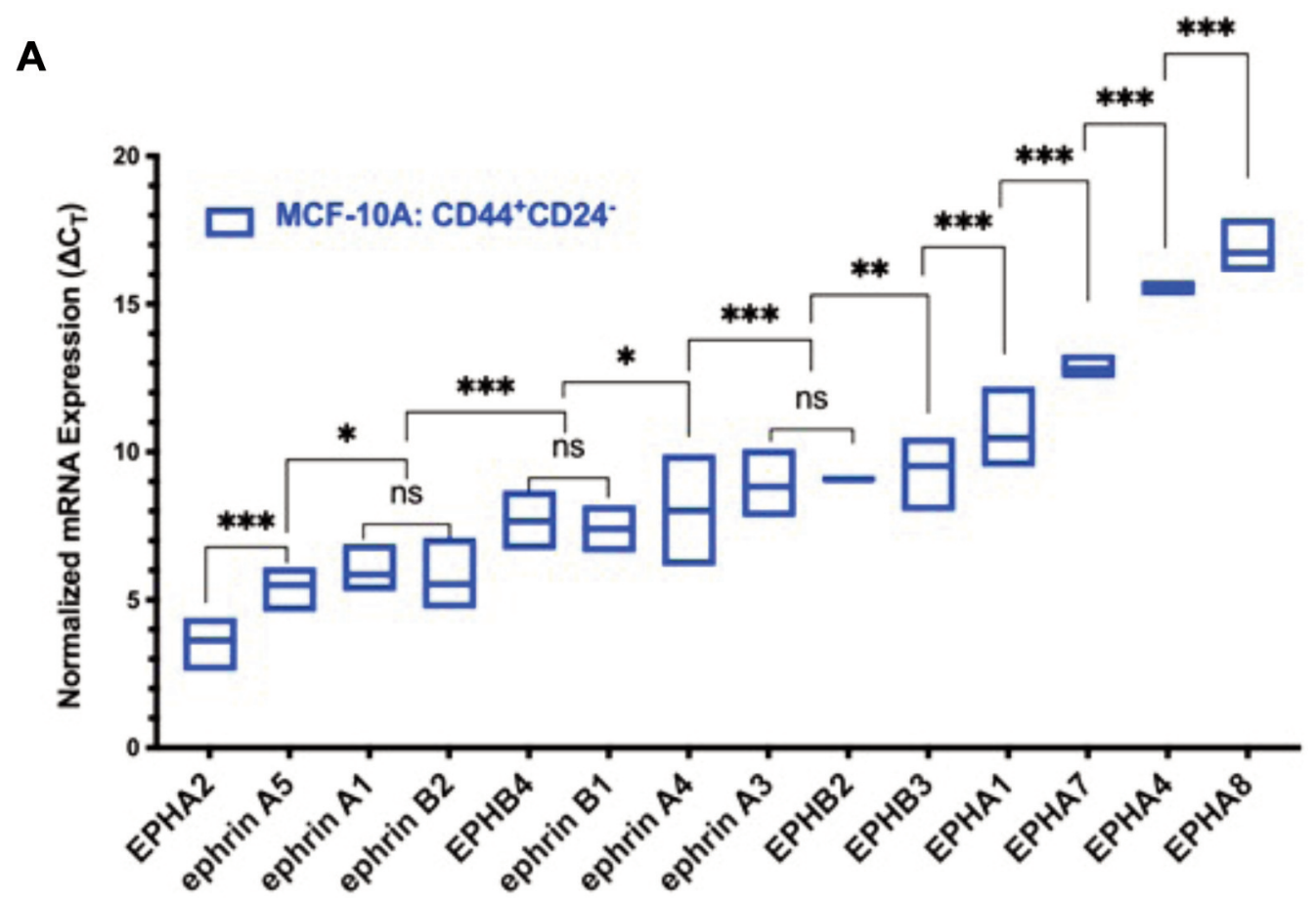

B

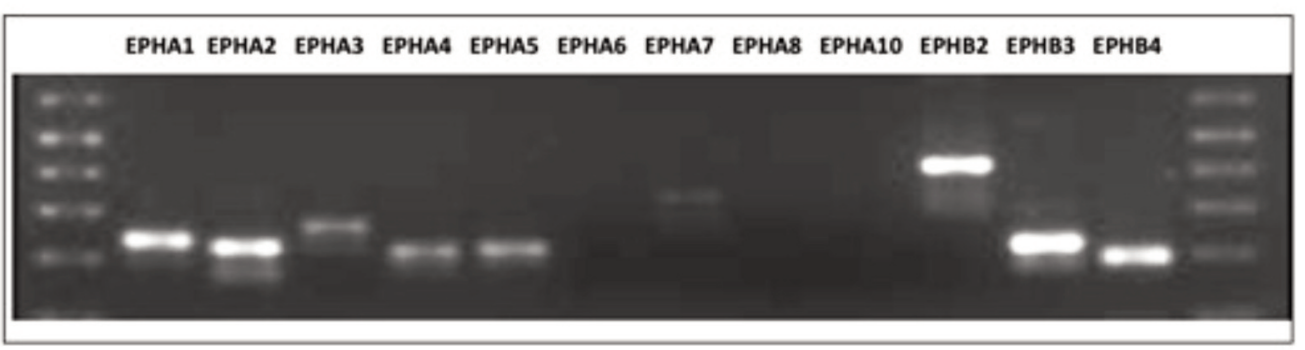

C

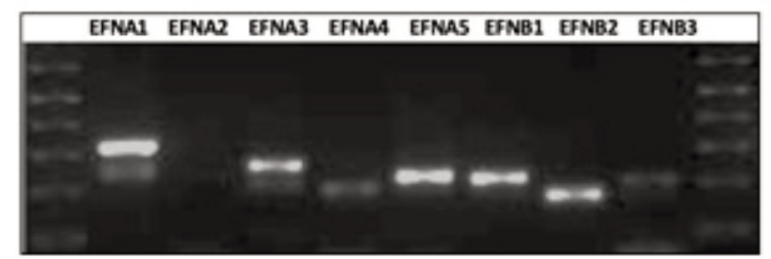

Figure 1. Expression pattern of EPH-ephrin transcripts in $C D 44^{+} C D 24^{-}$cells isolated from a non-tumorigenic breast epithelial cell-line (MCF10A). (A) Box Plot of $\Delta C_{T}$ values ranked in order of decreasing abundance. $\Delta C_{T}$ value of three biological replicates is represented as the mean $\pm S D . \Delta C_{T}$ values were obtained by normalizing EPH-ephrin to PPIA expression. Differences in $\Delta C_{T}$ values between transcripts were measured via two-way ANOVA and Tukey's Post Hoc Multiple Comparisons test: $*^{* *} p<0.001,{ }^{*} p<0.002,{ }^{*} p<0.03, p>0.01$ (not significant). (B) Amplified EPH receptor electrophoresed on $2.0 \%$ agarose gel after 40 cycles of amplification. (C) Amplified ephrin ligands electrophoresed on $2.0 \%$ agarose gel after 40 cycles of amplification.

followed by ephrin-A5, ephrin-B2, and ephrin-A1, which had mean $\Delta \mathrm{C}_{\mathrm{T}}$ values of $5.4,5.5$, and 5.8 respectively. The difference in normalized gene expression between these three transcripts was not significant indicating that these ligands are expressed in relatively equal abundance. EPHB 4 was present in the highest abundance. The transcripts for EPHB4 and ephrin-B1 had mean $\Delta \mathrm{C}_{\mathrm{T}}$ values of 7.6 and 7.4 respectively. The mean $\Delta \mathrm{C}_{\mathrm{T}}$ for ephrin-A4 was significantly lower than ephrin-A3 and EPHB2, which were expressed in relatively equal abundance. EPHB3 and EPHA1 also showed robust expression in $\mathrm{CD} 44^{+} / \mathrm{CD} 24^{-}$cells with mean $\Delta \mathrm{C}_{\mathrm{T}}$ values of 9.5 and 10.5, respectively. Receptors EPHA1, 
EPHA4, EPHA8 were the least expressed transcripts; faint bands for EPHA7 and EPHA4 were visible on agarose gel, whereas EPHA8 was not detectable. Although, qPCR data indicate that EPHA3 is expressed in a very low abundance, a signal was not determined for every technical replicate hence the expression of EPHA3 in MCF10A stem-like cells cannot be confirmed under the experimental parameters used. The overall ranking of $\mathrm{EPH} /$ ephrin transcript abundance in the stem-like cells isolated from nontumorigenic breast epithelial cell is as follows: EPHA2 > ephrin-A5 > (ephrin-A1, ephrin-B2) $>$ (EPHB4, ephrin-B1) $>$ ephrin-A4 $>($ EPHB2, ephrin-A3) $>$ EPHB3 $>$ EPHA1 $>$ EPHA7 $>$ EPHA4 $>$ EPHA8. A qualitative pattern of expression for various Eph receptors and ephrin ligands in MCF10A stem-like cells is shown in Figures 1B and C.

EPH/ephrin transcript expression profiles in $C D 44^{+} / C D 24^{-}$ cells from invasive triple-negative breast carcinoma cells (MDA-MB-231). As shown in Figure $2 \mathrm{~A}$, the $\mathrm{CD} 44^{+} / \mathrm{CD} 24^{-}$ stem-like cells isolated from invasive, triple-negative breast carcinoma cell line MDA-MB-231 have a distinct expression pattern of EPH/ephrin ligands. Transcripts for EPHA3, EPHA6, and ephrin-A2 were not detectable in this cell-line under the experimental parameters. The transcript for ephrinA5 was expressed in the highest abundance overall with a mean $\Delta \mathrm{C}_{\mathrm{T}}$ value of 3.5 , EPHA2 was the most robustly expressed A-class receptor with mean $\Delta C_{T}$ value of 5.1, and EPHB2 was the B-class receptor expressed in the highest abundance. However, receptors EPHA 8 and EPHB2 were expressed at relatively equal abundance with mean $\Delta \mathrm{C}_{\mathrm{T}}$ values of 7.9. The abundance of EPHA8 was significantly higher in the stem-like cells isolated from MDA-MB-231 which is in stark contrast to the stem-like cells isolated from MCF10A. Ephrin-B2 was the next highest ranked transcript with a mean $\Delta \mathrm{C}_{\mathrm{T}}$ value of 8.3. The transcripts for EPHA7, EPHB4, and ephrin-A4 were present in a relatively equal abundance $\left(\Delta \mathrm{C}_{\mathrm{T}}\right.$ values 9.2, 9.7, and 9.4, respectively). Signals were also detected for ephrin-A3 (10.3), ephrin-A1 (10.8), ephrin-B1 (11.8), and EPHA4 (12.2). Receptors EPHA1 and EPHB3 were expressed in relatively equal abundance (mean $\Delta \mathrm{C}_{\mathrm{T}}$ values of 12.9 and 13.0). The least expressed transcript was EPHA10 with mean $\Delta \mathrm{C}_{\mathrm{T}}$ value of 15.9. According to $q P C R$ data, the relative abundance of EPH/ephrin transcripts in $\mathrm{CD} 44^{+} / \mathrm{CD} 24^{-}$cells isolated from invasive MDA-MB-231 is as follows: ephrin-A5 > EPHA2 $>$ (EPHA8, EPHB2) > ephrin-B2 > (EPHA7, EPHB4, ephrin-A4) $>$ ephrin-A3 > ephrin-A1 > (EPHB3, ephrin-B1 $)$ $>$ EPHA4 $>$ EPHA1 $>$ EPHA10. A qualitative pattern of expression for various Eph receptors and ephrin ligands in MDA-MB-231 stem-like cells is shown in Figure 2B and C.

Quantitative differences in Eph/ephrin transcripts in $\mathrm{CD} 44^{+} / \mathrm{CD} 24^{-}$and $\mathrm{CD} 44^{+} / \mathrm{CD} 24^{+}$cells isolated from
$M C F 10 A$. There was no significant difference in the $\Delta \mathrm{C}_{\mathrm{T}}$ values for EPHA4, EPHA5, EPHB2, EPHB3, ephrin-A4, ephrin-B1, ephrin-B2 and ephrin-B3 suggesting that these transcripts are expressed at relatively equal abundance in both the stem-like and differentiated bulk cells. All other transcripts showed significant changes in abundance (Figure 3A). While EPHA1, EPHA7, EPHA8, and ephrin-A5 were all down-regulated in the $\mathrm{CD} 44^{+} / \mathrm{CD} 24^{-}$stem-like cell fraction relative to the $\mathrm{CD} 44^{+} / \mathrm{CD} 24^{+}$bulk cell fraction, EPHA2, ephrin-A1, and ephrin-A3 were up-regulated (Figure 3C). EPHA8 and ephrin-A3 displayed the greatest differences in expression between the stem-like and bulk cell fractions. Ephrin-A3 was significantly up-regulated by 20 fold in the stem-like cell fraction. Moreover, EPHA2 as well its preferred ligand, ephrin-A1, are both comparably upregulated by 7.0 and 6.0-fold respectively, and EPHA 8 was decreased by $~ 11$-fold. In addition, EPHA1, EPHA7, and ephrin-A5 (cognate ligand of EPHA8) were down-regulated in the stem-like cell fraction by $6.8,8.0$, and 6.8 -fold respectively (Figure 3E).

Quantitative differences in Eph/ephrin transcripts in $\mathrm{CD} 44^{+} / \mathrm{CD} 24^{-}$and $\mathrm{CD} 44^{+} / \mathrm{CD} 24^{+}$cells isolated from $\mathrm{MDA}$ $M B-231$. As shown in Figure $3 \mathrm{~B}$, there was a significant difference in normalized gene expression $\left(\Delta \mathrm{C}_{\mathrm{T}}\right)$ between the stem-like and bulk cells for the transcripts corresponding to EPHA2, EPHA4, EPHA7, EPHA8, EPHB2, EPHB3, ephrinA1, ephrin-A3, and ephrin-A5. All other detectable transcripts were expressed in relatively equal abundance in both the stem-like cells and the bulk cells. Ephrin-A1 was the only transcript down-regulated in the stem-like cell fraction, which was down-regulated by $\sim 4.3$-fold (Figure 3D). The transcripts for EPHA2, EPHA4, EPHA7, EPHA8, EPHB2, EPHB3, ephrin-A3, and ephrin-A5 were all upregulated by $\sim 41,15,20,160,12,7,26$, and 3.6-fold respectively (Figure 3F). Similar to MCF-10A, EPHA8 and ephrin-A3 displayed the greatest difference in expression between the stem-like and differentiated cell fractions. However, in contrast both EPHA8 and ephrin-A3 and their preferred binding partners, ephrin-A5 and EPHA4, were also up-regulated in the stem-like cell fraction relative to the differentiated bulk cells (Figure 3F).

Comparative analysis of EPH receptor and ephrin ligand expression in $\mathrm{CD}_{4} 4^{+} / \mathrm{CD} 24^{-}$cells isolated from normal and carcinoma breast cell-lines. When evaluating the qualitative differences in EPH/ephrin expression in the CD44 ${ }^{+} / \mathrm{CD} 24^{-}$ cells isolated from MDA-MB-231 and MCF-10A, EPHA10 was the only transcript that was differentially expressed. EPHA10 was not detectable in MCF10A, but a faint signal was detected in the stem-like cells isolated from MDA-MB231. The transcripts for EPHA3, EPHA6, and ephrin-A2 were not detectable in both $\mathrm{CD} 44^{+} / \mathrm{CD} 24^{-}$and 


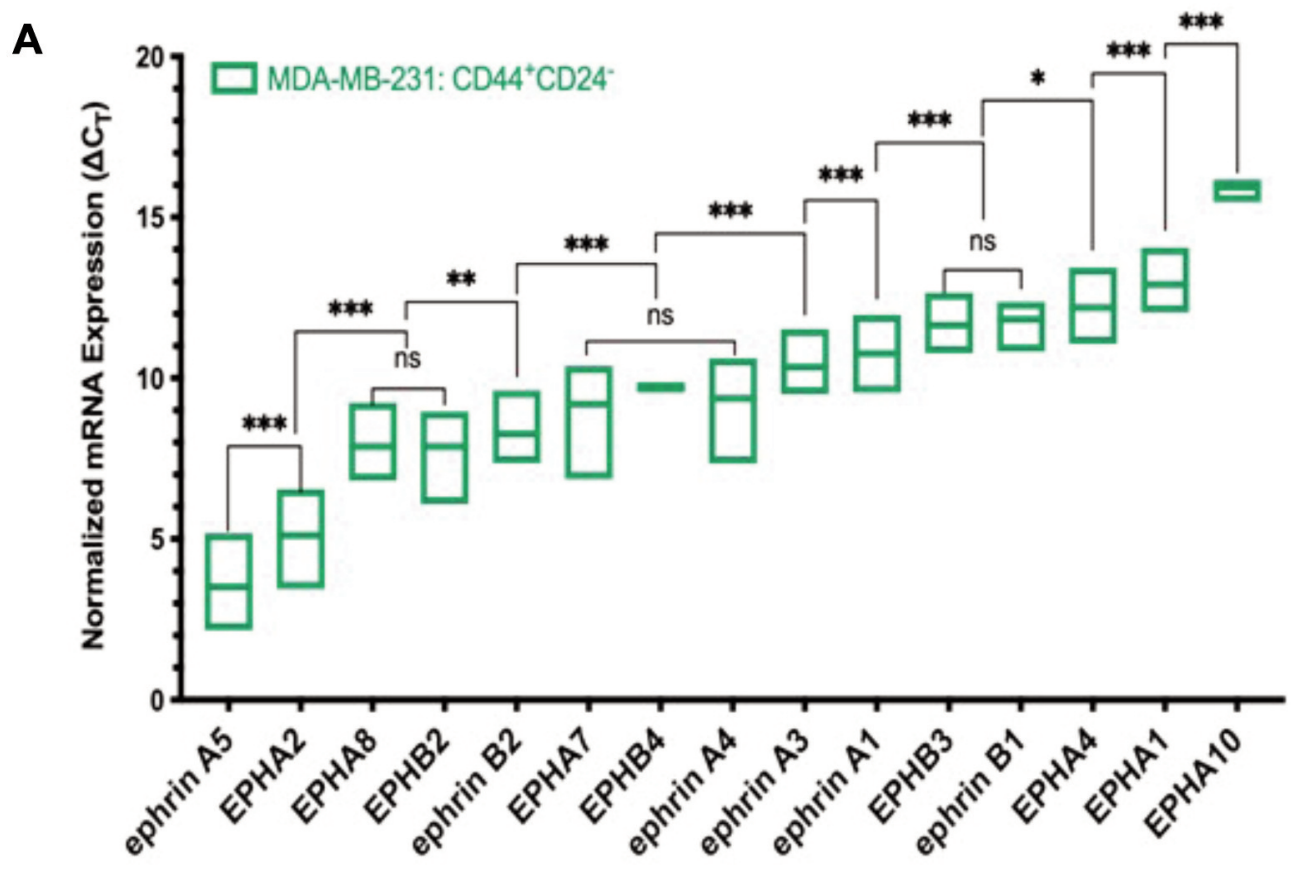

$\mathbf{B}$

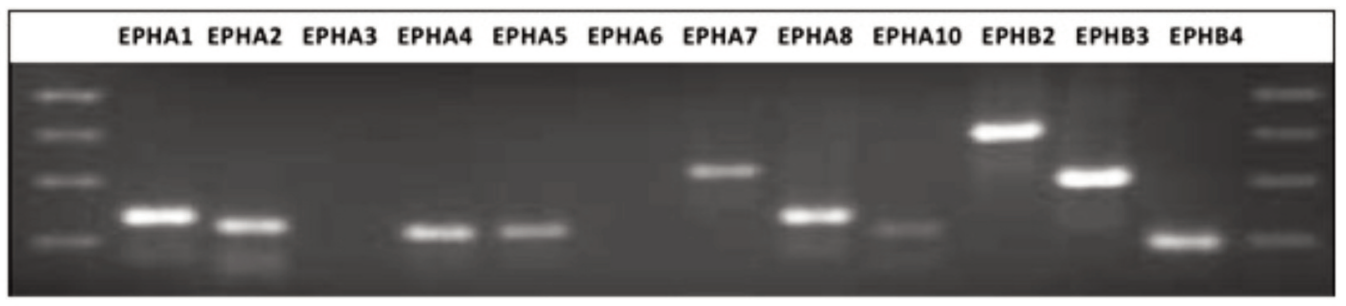

C

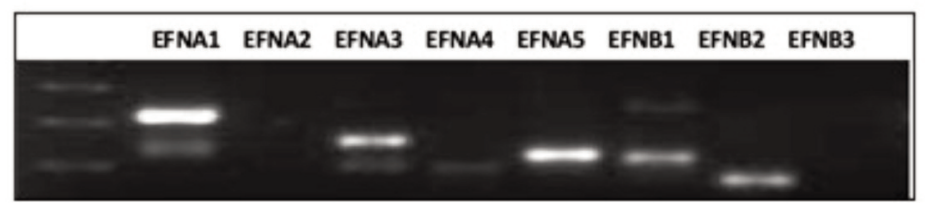

Figure 2. Expression pattern of EPH-ephrin transcripts in $C D 44^{+} C D 24^{-}$cells isolated from invasive, triple-negative breast carcinoma cells (MDA$M B-231)$. (A) Box Plot of $\Delta C_{T}$ values ranked in order of decreasing abundance. $\Delta C_{T}$ value of three biological replicates is represented as the mean $\pm S D . \Delta C_{T}$ values were obtained by normalizing EPH-ephrin to PPIA expression. Differences in $\Delta C_{T}$ values between transcripts were measured via two-way ANOVA and Tukey's Post Hoc Multiple Comparisons test: $* * * p<0.001$, **p $<<0.002, * p<0.03, p>0.01$ (not significant). (B) Amplified EPH receptor electrophoresed on $2.0 \%$ agarose gel after 40 cycles of amplification. (C) Amplified ephrin ligands electrophoresed on $2.0 \%$ agarose gel after 40 cycles of amplification.

$\mathrm{CD} 44^{+} / \mathrm{CD} 24^{+}$cells isolated from the MDA-MB-231 and MCF10A cell lines (Figure 4A). All other differences in EPH/ephrin transcript expression were quantitative. There was a significant difference in the normalized EPH/ephrin expression $\left(\Delta \mathrm{C}_{\mathrm{T}}\right)$ for the stem-like cell fractions isolated from MDA-MB-231 and MCF10A for all detectable transcripts, with the exception of EPHA2, EPHB2, and ephrin-A4 (Figure 4A). These findings suggest there is a negligible difference in transcript abundance for EPHA2, EPHB2, and ephrin-A4 in the stem-like cell fractions isolated from these phenotypically distinct cell-lines. The transcripts for EPHA4, EPHA7, EPHA8 and ephrin-A5 were up-regulated in MDA-MB-231 CD $44^{+} / \mathrm{CD} 24^{-}$cells relative to MCF10A (Figure 4B). EPHA8 was up-regulated by $486-$ fold (mean $\Delta \Delta \mathrm{C}_{\mathrm{T}}$ of -8.9). Transcripts for EPHA7 and EPHA4 were also up-regulated by $\sim 20.2$ and $\sim 12.3$-fold with 
A

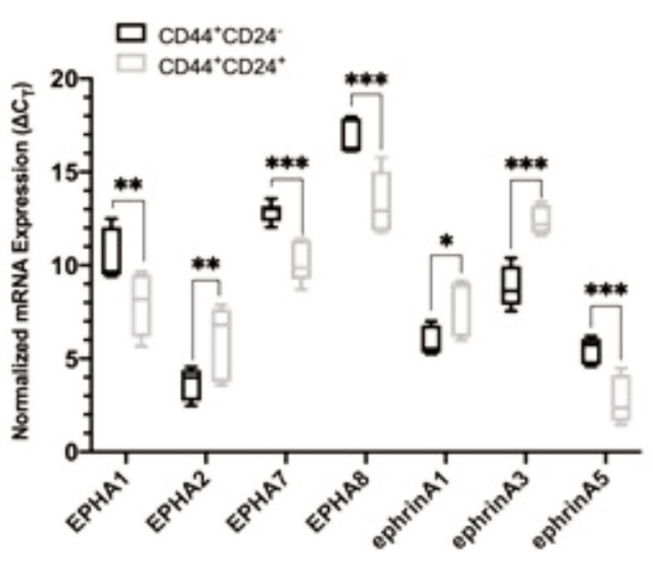

C

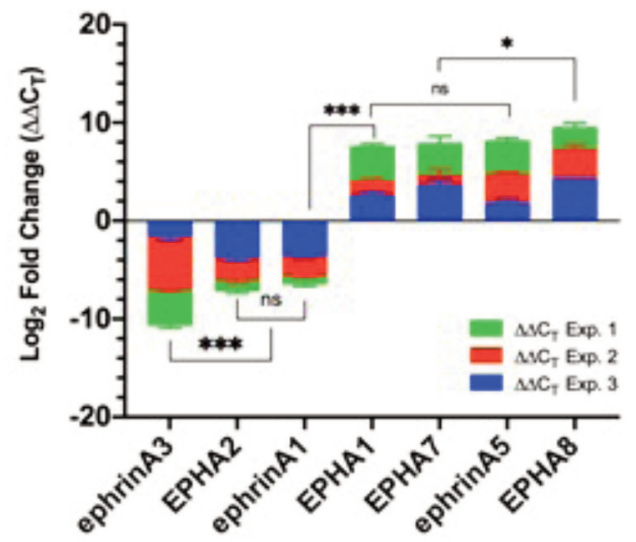

E

\begin{tabular}{|c|c|}
\hline \multicolumn{2}{|c|}{ MCF-10A } \\
\hline Gene & Fold Change \\
\hline EPHA1 & .6 .8 \\
\hline EPHA2 & 7.0 \\
\hline EPHA7 & -2.7 \\
\hline EPHAB & -11.0 \\
\hline ephrinA1 & 4.5 \\
\hline ephrinA3 & 20.3 \\
\hline ephrinA5 & -6.6 \\
\hline
\end{tabular}

B
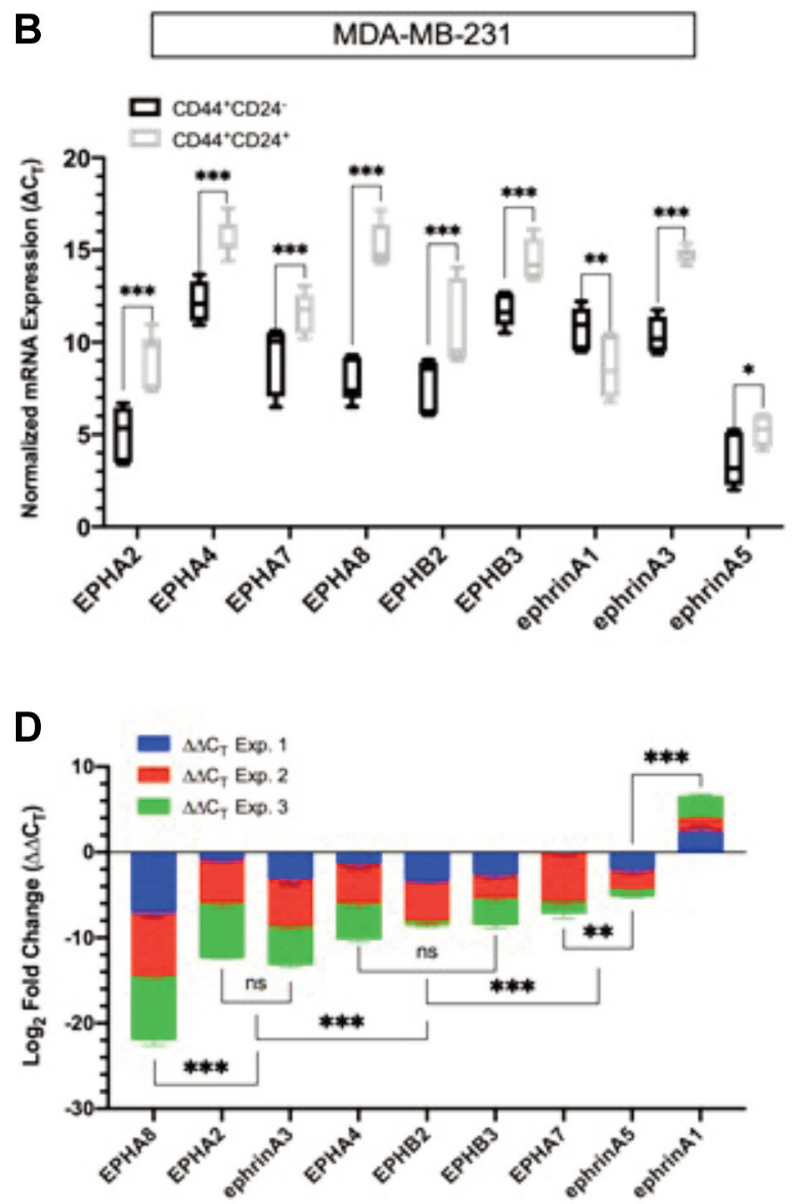

$\mathbf{F}$

\begin{tabular}{|c|c|}
\hline \multicolumn{2}{|c|}{ MDA-MB-231 } \\
\hline Gene & Fold Change \\
\hline EPHA2 & 41.0 \\
\hline EPHA4 & 15.3 \\
\hline EPHA7 & 19.9 \\
\hline EPHAB & 162.4 \\
\hline EPHB2 & 12.8 \\
\hline EPHB3 & 7.3 \\
\hline ephrinA1 & -4.3 \\
\hline ephrinA3 & 26.4 \\
\hline ephrinA5 & 3.6 \\
\hline $\begin{array}{l}r<0 \text { Fols } \\
;>0 \text {. Fols }\end{array}$ & $\begin{array}{l}=2^{\text {teuch }} \\
=1 / 2^{2} \text { suct }\end{array}$ \\
\hline
\end{tabular}

Figure 3. Comparative analysis of EPH/ephrin expression in $C D 44^{+} / C D 24^{-}$and $C D 44^{+} / C D 24^{+}$cells. (A) Box and whisker plot of EPH/ephrin normalized $m R N A$ expression in $C D 44^{+} / C D 24^{-}$and $C D 44^{+} / C D 24^{+}$cells from $M C F 10 A . \triangle C_{T}$ values are represented as the mean $\pm S D$ of three biological replicates. $\Delta C_{T}$ values were obtained by normalizing EPH-ephrin expression by PPIA expression. Differences in $\Delta C_{T}$ values between transcripts were measured via two-way ANOVA and Sidak's Post Hoc Multiple Comparisons test: ${ }^{* *} p<0.001, * * p<0.002, * p<0.03, p>0.01$ (not significant). (B) Box and whisker plot of EPH/ephrin normalized mRNA expression in $C D 44^{+} / C D 24^{-}$and $C D 44^{+} / C D 24^{+}$cells from MDA-MB-231. (C) Stacked Bar graph of $\triangle \triangle C_{T}$ values ranked in order of decreasing abundance in MCF10A. The mean $\Delta \Delta C_{T}$ values were calculated by normalizing $\Delta C_{T}$ values the CD44+/CD24- stem-like cell fraction relative to the $C D 44^{+} / C D 24^{+}$differentiated cell fraction isolated from the same cell-line. Negative $\triangle \triangle C_{T}$ values indicate an up-regulation and positive $\Delta \Delta C_{T}$ values indicate a down-regulation. (D) Stacked Bar graph of $\Delta \Delta C_{T}$ values ranked in order of decreasing abundance in MDA-MB231. (E) Mean fold change for transcripts corresponding to MCF10A. For $\Delta \Delta C_{T}<0$, fold change was calculated using the equation $2^{\wedge}-(\Delta \Delta C T)$. For $\Delta \triangle C_{T}>0$, fold change was calculated using the equation $-1 / 2^{\Lambda}-(\Delta \Delta C T)$. (F) Mean fold change for transcripts corresponding to MDA-MB-231. 

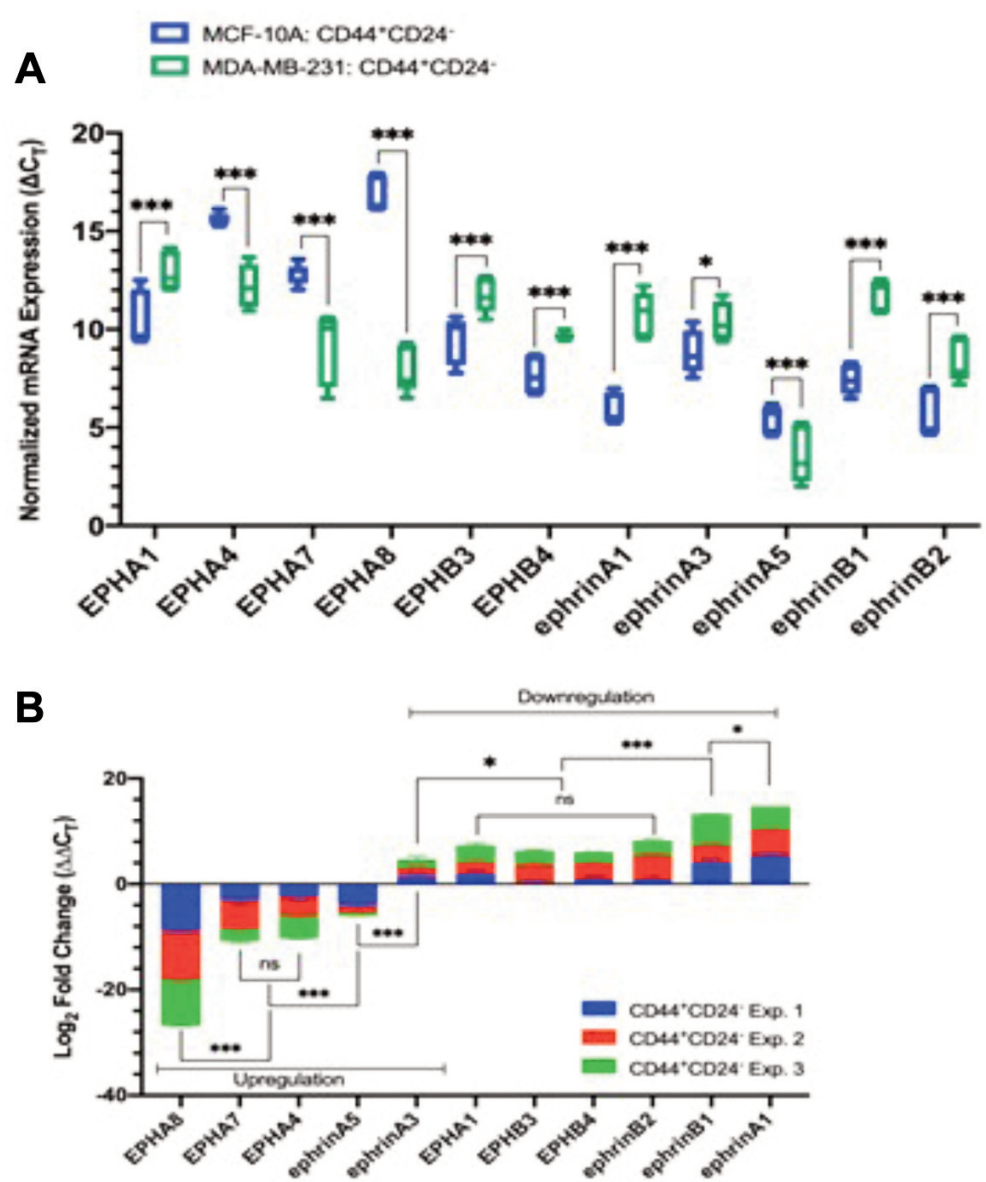

C

\begin{tabular}{|c|c|}
\hline Gene & Mean \\
\hline EPHA1 & -5.8 \\
\hline ЕРНА4 & 12.3 \\
\hline EPHA7 & 20.3 \\
\hline EPHA8 & 486.3 \\
\hline ЕРНB3 & -2.8 \\
\hline ЕРНВ4 & -4.9 \\
\hline ephrinA1 & -31.3 \\
\hline ephrinas & -2.9 \\
\hline ephrinAs & 6.5 \\
\hline ephrinB1 & -26.9 \\
\hline ephrinB2 & -11.8 \\
\hline $\begin{array}{l}A M C_{T}<0: \text { Fold } C= \\
A N C_{1}>0 \text { : Fold }\end{array}$ & Cris \\
\hline
\end{tabular}

Figure 4. Relative difference in EPH/ephrin expression in $C D 44^{+} C D 24^{-}$cells isolated from invasive triple-negative breast carcinoma cells (MDA-MB231) and non-tumorigenic breast epithelial cells (MCF-10A): (A) Box and whisker plot of EPH/ephrin normalized mRNA expression in CD44 $/ C D 24^{-}$. $\Delta C_{T}$ values are represented as the mean $\pm S D$ of three biological replicates. $\Delta C_{T}$ values were obtained by normalizing EPH-ephrin expression by PPIA expression. Differences in $\Delta C_{T}$ values between transcripts were measured via two-way ANOVA and Sidak's Post Hoc Multiple Comparisons test: $*^{* *} p<0.001, * * p<0.002, * p<0.03, p>0.01$ (not significant). (B) Stacked Bar graph of $\Delta \Delta C_{T}$ values ranked in order of decreasing abundance. $\Delta \Delta C_{T}$ values were caluculated by normalizing $\Delta C_{T}$ values for $C D 44^{+} C D 24^{-}$cells isolated from $M D A-M B-231$ by the $\triangle C_{T}$ values for $C D 44^{+} C D 24^{-}$cells isolated from MCF-10A. The mean $\Delta \Delta C_{T}$ value for each experiment is represented as the mean $\pm S D$. The differences in $\triangle \triangle C_{T}$ values between transcripts were measured via two-way ANOVA and Sidak's Post Hoc Multiple Comparisons test: ${ }^{* * *} p<0.001,{ }^{* *} p<0.002,{ }^{*} p<0.03, p>0.01$ (not significant). Negative $\Delta \triangle C_{T}$ values indicate an up-regulation and positive $\Delta \Delta C_{T}$ values indicate a down-regulation. (C) Mean fold change for indicated transcripts. For $\Delta \Delta C_{T}$ $<0$, fold change was calculated using the equation $2^{\Lambda-(\Delta \Delta C T)}$. For $\Delta \Delta C_{T}>0$, fold change was calculated using the equation $-1 / 2^{\wedge-}(\Delta \Delta C T)$. 
mean $\Delta \Delta \mathrm{C}_{\mathrm{T}}$ of -3.6 and -3.4. Ephrin-A5 was the only ligand that was up-regulated ( 6.5-fold; $\Delta \Delta \mathrm{C}_{\mathrm{T}}$ of -1.9). Ephrin-A3 was slightly down-regulated by $\sim 2$.9-fold (mean $\Delta \Delta \mathrm{C}_{\mathrm{T}}$ of 1.5). Transcripts for EPHA1, EPHB3, EPHB4, and ephrinB2 were down-regulated in the MDA-MB-231 stem cell fraction by approximately 5.8, 2.8, 4.9, 3.9-fold with negligible differences in $\Delta \Delta \mathrm{C}_{\mathrm{T}}$ values $(2.4,2.1,2.0,2.7)$. Ephrin-B1 and ephrin-A1 were the most down-regulated transcripts overall. These transcripts were down-regulated by $\sim 27$-fold and $\sim 31$-fold, respectively (Figure $4 \mathrm{C}$ ). Therefore, the relative abundance of EPH/ephrin transcripts in MDAMB-231 relative to MCF10A is as follows: EPHA8 > $($ EPHA7, EPHA4) $>$ ephrin-A5 $>$ ephrin-A3 > (EPHA1, EPHB3, EPHB4, ephrin-B2) > ephrin-B1 > ephrin-A1 .

\section{Discussion}

The analysis of EPH/ephrin expression in $\mathrm{CD} 44^{+} \mathrm{CD} 24^{-}$ stem-like cells isolated from non-tumorigenic (MCF10A) and invasive breast carcinoma (MDA-MB-231) cells revealed that distinctive EPH/ephrin molecular signatures are inherent to each cell line and may contribute to the breast stem-like cell phenotype. As seen in MCF10A, EPH/ephrin expression is stringently regulated in non-tumorigenic mammary stem cells (16) wherein a variety of EPH/ephrin genes associated with tumorigenesis and invasiveness were either not detectable or suppressed in the $\mathrm{CD} 44^{+} \mathrm{CD} 24^{-}$fraction. In quiescent stem cells, genes responsible for cell proliferation are often downregulated, while cell-fate determination genes are frequently up-regulated (18). Thus, the differences in EPH/ephrin expression in $\mathrm{CD} 44^{+} \mathrm{CD} 24^{-}$cells isolated from nontumorigenic and invasive breast epithelial cells lines may contribute to the functional differences in stem-cell proliferation and/or stem-cell quiescence observed in these phenotypically distinct cell-lines.

For instance, the differential expression of ephrin-A1 and ephrin-A5 in the non-tumorigenic and invasive breast carcinoma cell lines was notable. In MCF-10A, ephrin-A1 was up-regulated while ephrin-A5 was down-regulated. Conversely, in MDA-MB-231, ephrin-A1 was downregulated while ephrin-A5 was up-regulated. These findings are significant in the context of the receptor-ligand pairs, which are up-regulated in the stem-like cells relative to the bulk cells for each cell line. EPHA2 was the only receptor up-regulated in MCF10A, whereas several receptors were up-regulated in MDA-MB-231, including both EPHA2 and EPHA8. The up-regulation of EPHA2 in cancer stem-like cells enhances the self-renewal capacity of the CSC population, whereas ephrin-A1 expression negatively regulates EPHA2-mediated CSC proliferation (19). Therefore, EPHA2/ephrin-A1 forward signaling in MCF10A may contribute to the reduced stem-like cell fraction observed in this cell line. Conversely, the suppression of
ephrin-A1 expression in the MDA-MB-231 stem-like cell fraction facilitates ligand-independent activation of EPHA2, which is associated with increased stem-cell pluripotency (19), and contributes to the increased stem-like cell fraction observed in this cell line.

Moreover, EPHA8 and its cognate ligand ephrin-A5 were up-regulated in MDA-MB-231 and down-regulated in MCF10A. This Eph/ephrin pair appears to influence the stemlike cell dynamics in these cell lines. The systematic comparison of EPH/ephrin transcripts in the $\mathrm{CD} 44^{+} / \mathrm{CD} 24^{-}$ cells isolated from MDA-MB-231 and MCF10A revealed that receptors EPHA8, EPHA7, EPHA4, and ephrin-A5 were significantly up-regulated in the stem-like cells isolated from invasive breast carcinoma cells. On the other hand, the transcripts for EPHA1, EPHB3, EPHB4, ephrin-A1, ephrinA3, ephrin-B1 and ephrin-B2 were significantly downregulated. The down-regulation of EPHB/ephrin-B pairs in MDA-MB-231 cells suggests the involvement of EPHB receptor class in suppressing the BCSC niche. This explanation is supported by the observations indicating the regulation of stem cell proliferation by EPHB/ephrin-B signaling (20), which has been shown to attenuate cell migration and cell differentiation (21). These receptors and ligands have been implicated in activities that regulate the cancer cell communication with tumor-associated monocytes (22), stem/progenitor cell maintenance and cell migration through Rac1 activation (23). In light of our observations with Eph/ephrin profiles of cancer stem cells presented here and reported involvement of these molecules in cancer invasiveness, we postulate that the suppression of EphB receptors, ephrin-B and ephrin-A1 ligands in combination with the upregulation of EPHA8, EPHA7, EPHA4 and ephrin-A5 may contribute to the invasiveness of MDA-MB-231 cells.

Although the role of EPHA8 in cancer stem cells remains elusive, its overexpression correlates to a poor overall survival in other human malignancies, such as epithelial ovarian cancer (EOC) (24-26). In EOC, both EPHA8 and ephrin-A5 are significantly up-regulated (24), while only EPHA8 was reported to be overexpressed in OTSCC and GC (25). In gastric cancer cells, the up-regulation of EPHA8 gene occurs with the up-regulation of the $\beta$-catenin gene (27). Wnt $/ \beta$ catenin and PI3K/Akt signaling has been shown to promote EMT of gastric cancer cells (28). Interestingly, BCSCs display significantly increased $\mathrm{Wnt} / \beta$-catenin signaling relative to the non-tumorigenic bulk cells (29), and the aberrant activity of $\mathrm{Wnt} / \beta$-catenin is implicated in the acquisition of the BCSC phenotype $(30,31)$. Moreover, miR-10a mediates glioma cell migration and invasion by negatively regulating EphA8 to induce EMT (32). Although no data regarding the involvement of EPHA8 signaling in breast cancer stem-like cells is available, it is known to alter the expression of cell-cycle regulatory proteins, matrix metalloproteinases, AKT pathway (26), PI-3 kinase pathway (33), and sustained MAPK activation 
(34). Based on significant alteration in EphA8/ephrin-A5 abundance, we hypothesize that either EPHA8 mediates cancer stem cells transition from quiescent to proliferative state in the milieu of MDA-MB-231 environment or alternatively its constitutive expression in stem cells transforms stem cells as well as the bulk cells. Overall, our observations support previously reported data regarding the role of the EPH/ephrin in modulating stem-cell behavior (35), and contribute to our current understanding of how the altered expression of the $\mathrm{EPH} /$ ephrin gene family may influence the distinct functional and cellular phenotypes of breast cancer. In particular, the established role of EphA8/ephrin-A5 in facilitating PI3 KinaseAkt-MAP kinase axis points to a probable interaction of cancer stem cells and bulk cancer cells to determine the overall phenotype of breast tumors.

\section{Conflicts of Interest}

The Authors declare no conflicts of interest.

\section{Authors' Contributions}

ML designed/executed the experiments, analyzed the data and wrote the manuscript; JT, JS, SS and BJ contributed to preliminary experiments of cell culture, cell isolation, and RT-PCR; RPK served as PI, designed the project/experiments, supervised the overall project and wrote the manuscript.

\section{Acknowledgements}

The Authors wish to thank our colleagues for making their facilities available from time to time.

\section{References}

1 Siegel RL, Miller KD and Jemal A: Cancer statistics, 2019. CA Cancer J Clin 69(1): 7-34, 2019. PMID: 30620402. DOI: $10.3322 /$ caac. 21551

2 Lemma S, Avnet S, Salerno M, Chano T and Baldini N: Identification and validation of housekeeping genes for gene expression analysis of cancer stem cells. PLoS One 11(2): e0149481, 2016. PMID: 26894994. DOI: 10.1371/journal.pone. 0149481

3 Al-Hajj M, Becker MW, Wicha M, Weissman I and Clarke MF: Therapeutic implications of cancer stem cells. Curr Opin Genet Dev 14(1): 43-47, 2004. PMID: 15108804. DOI: 10.1016/j.gde.2003. 11.007

4 Dawood S, Austin L and Cristofanilli M: Cancer stem cells: Implications for cancer therapy. Oncology (Williston Park) 28(12): 1101-1107, 1110, 2014. PMID: 25510809.

5 Kai M, Kanaya N, Wu SV, Mendez C, Nguyen D, Luu T and Chen S: Targeting breast cancer stem cells in triple-negative breast cancer using a combination of 1 bh589 and salinomycin. Breast Cancer Res Treat 151(2): 281-294, 2015. PMID: 25904215. DOI: $10.1007 / \mathrm{s} 10549-015-3376-5$

6 Luo M, Brooks M and Wicha MS: Epithelial-mesenchymal plasticity of breast cancer stem cells: Implications for metastasis and therapeutic resistance. Curr Pharm Des 21(10): 1301-1310, 2015. PMID: 25506895. DOI: 10.2174/1381612821666141211120604

7 Johnson C, Segovia B and Kandpal RP: Epha7 and epha10 physically interact and differentially co-localize in normal breast and breast carcinoma cell lines, and the co-localization pattern is altered in ephb6-expressing mda-mb-231 cells. Cancer Genomics Proteomics 13(5): 359-368, 2016. PMID: 27566654.

8 Fox BP and Kandpal RP: Invasiveness of breast carcinoma cells and transcript profile: Eph receptors and ephrin ligands as molecular markers of potential diagnostic and prognostic application. Biochem Biophys Res Commun 318(4): 882-892, 2004. PMID: 15147954. DOI: 10.1016/j.bbrc.2004.04.102

9 Bhushan L and Kandpal RP: Ephb6 receptor modulates micro rna profile of breast carcinoma cells. PLoS One 6(7): e22484, 2011. PMID: 21811619. DOI: 10.1371/journal.pone.0022484

10 Bartley TD, Hunt RW, Welcher AA, Boyle WJ, Parker VP, Lindberg RA, Lu HS, Colombero AM, Elliott RL, Guthrie BA, Holst PA, Skrine JD, Toso RJ, Zhang M, Fernandez E, Trail G, Varnum B, Yarden Y, Hunter T and Fox GM: B61 is a ligand for the eck receptor protein-tyrosine kinase. Nature 368(6471): 558560, 1994. PMID: 8139691. DOI: 10.1038/368558a0

11 Gauthier LR and Robbins SM: Ephrin signaling: One raft to rule them all? One raft to sort them? One raft to spread their call and in signaling bind them? Life Sci 74(2-3): 207-216, 2003. PMID: 14607248. DOI: $10.1016 /$ j.lfs.2003.09.029

12 Kania A and Klein R: Mechanisms of ephrin-eph signalling in development, physiology and disease. Nat Rev Mol Cell Biol 17(4): 240-256, 2016. DOI: 10.1038/nrm.2015.16

13 Pasquale EB: Eph receptor signalling casts a wide net on cell behaviour. Nat Rev Mol Cell Biol 6(6): 462-475, 2005. PMID: 26790531. DOI: $10.1038 / \mathrm{nrm} 1662$

14 Pasquale EB: Eph-ephrin bidirectional signaling in physiology and disease. Cell 133(1): 38-52, 2008. PMID: 18394988. DOI: 10.1016/j.cell.2008.03.011

15 Kouros-Mehr H and Werb Z: Candidate regulators of mammary branching morphogenesis identified by genome-wide transcript analysis. Dev Dyn 235(12): 3404-3412, 2006. PMID: 17039550. DOI: $10.1002 /$ dvdy.20978

16 Kaenel P, Mosimann M and Andres AC: The multifaceted roles of eph/ephrin signaling in breast cancer. Cell Adh Migr 6(2): 138-147, 2012. PMID: 22568950. DOI: 10.4161/cam.20154

17 Schmittgen TD and Livak KJ: Analyzing real-time per data by the comparative c(t) method. Nat Protoc 3(6): 1101-1108, 2008. PMID: 18546601. DOI: 10.1038/nprot.2008.73

18 Cho IJ, Lui PP, Obajdin J, Riccio F, Stroukov W, Willis TL, Spagnoli F and Watt FM: Mechanisms, hallmarks, and implications of stem cell quiescence. Stem Cell Reports 12(6): 1190-1200, 2019. PMID: 31189093. DOI: 10.1016/j.stemcr.2019.05.012

19 Binda E, Visioli A, Giani F, Lamorte G, Copetti M, Pitter KL, Huse JT, Cajola L, Zanetti N, DiMeco F, De Filippis L, Mangiola A, Maira G, Anile C, De Bonis P, Reynolds BA, Pasquale EB and Vescovi AL: The epha2 receptor drives selfrenewal and tumorigenicity in stem-like tumor-propagating cells from human glioblastomas. Cancer Cell 22(6): 765-780, 2012. PMID: 23238013. DOI: 10.1016/j.ccr.2012.11.005

20 Holmberg J, Genander M, Halford MM, Anneren C, Sondell M, Chumley MJ, Silvany RE, Henkemeyer M and Frisen J: Ephb receptors coordinate migration and proliferation in the intestinal stem cell niche. Cell 125(6): 1151-1163, 2006. PMID: 16777604. DOI: 10.1016/j.cell.2006.04.030 
21 Batlle E, Henderson JT, Beghtel H, van den Born MM, Sancho E, Huls G, Meeldijk J, Robertson J, van de Wetering M, Pawson $\mathrm{T}$ and Clevers H: Beta-catenin and tcf mediate cell positioning in the intestinal epithelium by controlling the expression of ephb/ephrinb. Cell 111(2): 251-263, 2002. PMID: 12408869. DOI: $10.1016 / \mathrm{s} 0092-8674(02) 01015-2$

22 Lu H, Clauser KR, Tam WL, Frose J, Ye X, Eaton EN, Reinhardt F, Donnenberg VS, Bhargava R, Carr SA and Weinberg RA: A breast cancer stem cell niche supported by juxtacrine signalling from monocytes and macrophages. Nat Cell Biol 16(11): 11051117, 2014. PMID: 25266422. DOI: $10.1038 / \mathrm{ncb} 3041$

23 Nguyen TM, Arthur A, Zannettino AC and Gronthos S: Epha5 and epha7 forward signaling enhances human hematopoietic stem and progenitor cell maintenance, migration, and adhesion via rac1 activation. Exp Hematol 48: 72-78, 2017. PMID: 27988259. DOI: 10.1016/j.exphem.2016.12.001

24 Liu X, Xu Y, Jin Q, Wang W, Zhang S, Wang X, Zhang Y, Xu X and Huang J: Epha8 is a prognostic marker for epithelial ovarian cancer. Oncotarget 7(15): 20801-20809, 2016. PMID: 26989075. DOI: $10.18632 /$ oncotarget.8018

25 Liu L, Wang $X$ and Ge W: Epha8 is a prognostic factor for oral tongue squamous cell carcinoma. Med Sci Monit 24: 7213-7222, 2018. PMID: 30300334. DOI: 10.12659/MSM.910909

26 Wang Y, Zhou N, Li P, Wu H, Wang Q, Gao X, Wang X and Huang J: Epha8 acts as an oncogene and contributes to poor prognosis in gastric cancer via regulation of adam10. J Cell Physiol 234(11): 20408-20419, 2019. PMID: 31026069. DOI: $10.1002 /$ jcp. 28642

27 Tanabe S, Kawabata T, Aoyagi K, Yokozaki H and Sasaki H: Gene expression and pathway analysis of ctnnb1 in cancer and stem cells. World J Stem Cells 8(11): 384-395, 2016. PMID: 27928465. DOI: $10.4252 /$ wjsc.v8.i11.384

28 Song Y, Li ZX, Liu X, Wang R, Li LW and Zhang Q: The wnt/beta-catenin and pi3k/akt signaling pathways promote emt in gastric cancer by epigenetic regulation via h3 lysine 27 acetylation. Tumour Biol 39(7): 1010428317712617, 2017. PMID: 28671020. DOI: 10.1177/1010428317712617
29 Jang GB, Hong IS, Kim RJ, Lee SY, Park SJ, Lee ES, Park JH, Yun CH, Chung JU, Lee KJ, Lee HY and Nam JS: Wnt/betacatenin small-molecule inhibitor cwp232228 preferentially inhibits the growth of breast cancer stem-like cells. Cancer Res 75(8): 1691-1702, 2015. PMID: 25660951. DOI: 10.1158/00085472.CAN-14-2041

30 Jang GB, Kim JY, Cho SD, Park KS, Jung JY, Lee HY, Hong IS and Nam JS: Blockade of wnt/beta-catenin signaling suppresses breast cancer metastasis by inhibiting csc-like phenotype. Sci Rep 5: 12465, 2015. PMID: 26202299. DOI: 10.1038/srep12465

31 Xiang T, Li L, Yin X, Zhong L, Peng W, Qiu Z, Ren G and Tao Q: Epigenetic silencing of the wnt antagonist dickkopf 3 disrupts normal wnt/beta-catenin signalling and apoptosis regulation in breast cancer cells. J Cell Mol Med 17(10): 1236-1246, 2013. PMID: 23890219. DOI: $10.1111 / \mathrm{jcmm} .12099$

32 Yan Y, Wang Q, Yan XL, Zhang Y, Li W, Tang F, Li X and Yang P: Mir-10a controls glioma migration and invasion through regulating epithelial-mesenchymal transition via epha8. FEBS Lett 589(6): 756765, 2015. PMID: 25683004. DOI: 10.1016/j.febslet.2015.02.005

$33 \mathrm{Gu} \mathrm{C}$ and Park S: The epha8 receptor regulates integrin activity through p110gamma phosphatidylinositol-3 kinase in a tyrosine kinase activity-independent manner. Mol Cell Biol 21(14): 45794597, 2001. PMID: 11416136. DOI: 10.1128/MCB.21.14.45794597.2001

34 Gu C, Shim S, Shin J, Kim J, Park J, Han K and Park S: The epha8 receptor induces sustained map kinase activation to promote neurite outgrowth in neuronal cells. Oncogene 24(26): 4243-4256, 2005. PMID: 15782114. DOI: 10.1038/sj.onc.1208584

35 Gucciardo E, Sugiyama N and Lehti K: Eph- and ephrindependent mechanisms in tumor and stem cell dynamics. Cell Mol Life Sci 71(19): 3685-3710, 2014. PMID: 24794629. DOI: $10.1007 / \mathrm{s} 00018-014-1633-0$

Received September 2, 2020

Revised September 14, 2020

Accepted September 16, 2020 